\title{
Gene patents and personalized medicine
}

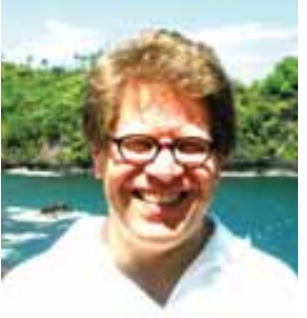

\section{Roger D Klein}

Yale U niversity School of Medicine,

$D$ epartment of $G$ enetics, $\mathrm{N}$ ew $\mathrm{H}$ aven, $\mathrm{CT}$, U SA

Tel.: +1 2168960568 ;

Fax: +1 2168960568 ;

E-mail: roger.klein@yale.edu

future, part of $\mathrm{fsg}$
'The introduction of genetic testing into the clinic al realm is beginning to collide head-on with patents that c la im ownership of correlations between human genetic variants and predisposition to disea se, individual response to therapeutic drugs and susceptibility to pharmacologic side effects.'

Molecular genetic testing has increasingly been incorporated into clinical medicine and this trend is likely to accelerate in the future [1,2]. A subset of this testing, the in vitro molecular analyses of genetic variations that influence the pharmacokinetic and pharmacodynamic properties of therapeutic drugs, is certain to play an important role in future medical practice. $\mathrm{H}$ owever, the introduction of genetic testing into the clinical realm is beginning to collide head-on with patents that claim ownership of correlations between human genetic variants and predisposition to disease, individual response to therapeutic drugs and susceptibility to pharmacologic side effects.

Holders or licensees of patents on genes, genetic variants and their biological correlations are al ready using the threat of litigation to prevent pathologists and other laboratory professionals from performing a number of diagnostically important molecular genetic tests. Such patents may present particular obstacles to our efforts to enhance pharmaceutical efficacy and reduce harmful side effects in the coming world of 'personalized medicine'.

Patent overview

A US patent confers the right to exclude others from making, using or selling an invention, such as a new pharmaceutical product, for 20 years from the filing date [3]. Although a patent gives its owner the authority to prevent others from making, using or selling his or her invention, a patent does not, in and of itself, bestow these affirmative legal privileges on an inventor. A patented diagnostic instrument, for example, may be constructed of multiple components, many of which have been patented by others.
An in vitro diagnostics manufacturer may need to obtain licenses from the holders of patents on a number of key components in order to make, use or sell the instrument. In addition, the sale and/or use of an invention, such as a new drug or medical device, may be subject to legal restrictions or regulatory approval.

Under the US Patent Act, patent-worthy inventions must be novel, non-obvious and useful [4]. A patent's claims define an invention's features, much as a deed delineates the boundaries of a plot of land. Patent applications are submitted to the US Patent O ffice (PTO) where they are allowed and issued, or rejected.

\section{History of gene patents}

Long controversial, 'gene patents' have recently been the subject of heightened media attention [5-7]. Author M ichael Crichton, a physician, joined the chorus of gene-patent critics in his novel N ext. Crichton went as far as to include an appendix to the book that exposed the 'evils' of gene patents and advocated a ban on them. In February 2007, Congressmen Xavier Becarra (Dem. CA) and D avid Weldon (Rep. FL) introduced The US Genomic Research and Accessibility Act (H.R. 977), a bill that would ban future patents on all nucleic acid sequences. Given this public debate, a review of the history of gene patenting is in order.

\footnotetext{
'The legitimization of gene patents was an outgrowth of legal and political changes initiated in response to the ec onomic dislocations of the late 1970s and early 1980s.'
}

The legitimization of gene patents was an outgrowth of legal and political changes initiated in response to the economic dislocations of the late 1970 s and early 1980 s. During this period, the USA was plagued by high unemployment, high inflation and a decline in economic confidence. In response, the US Congress took a number of steps to encourage the growth of domestic technology industries. Among the most significant of these were changes to the US patent system. 
To maximize the economic value derived from our substantial federal investments in basic science research, Congress in 1980 passed the Bayh-Dole Act [8]. Bayh-Dole encouraged universities to patent and commercialize inventions arising from governmentsponsored research grants. Accompanying the enactment of Bayh-D ole, and in the years subsequent to its passage, federal financial commitments dedicated to biomedical investigation increased dramatically. $\mathrm{NIH}$ funding of biomedical research ballooned from approximately U $\$ \$ 5$ billion in the late 1970 s to US\$26 billion in 2003 [9,101]. O wing to these governmental actions, the number of patents assigned to universities increased from 264 in 1979 to 3259 in 2003 [102].

0 ther important events took place on the legal front. In the landmark 1980 case of Diamond V. Chakrabarty [10], the US Supreme Court ruled that man-made, living organisms could be patented. Chakrabarty, a General Electric research scientist, applied for a patent on a Pseudomonas bacterium that was bioengineered to carry multiple plasmids. These plasmids conferred upon the newly created microorganism the ability to digest complex mixtures of hydrocarbons, potentially offering a biotechnological solution to oil-spill cleanup. The PTO rejected Chakrabarty's application, reasoning that living organisms were not patentable. Chakrabarty took the PTO 's decision to the courts and the case eventually made its way to the US Supreme Court. In upholding the patentability of Chakrabarty's invention, the $\mathrm{H}$ igh C ourt urged a broad interpretation of patent eligibility, holding that "anything under the sun that is made by man", including living organisms, can be patented.

'Other important events took place on

the legal front. In the landmark 1980

case of Diamond v. Chakrabarty, the US

Supreme Court ruled that man-made,

living organisms could be patented.'

Finally, in an effort to provide national uniformity and add greater certainty and expertise to the application of patent law, in 1982 Congress created a national appeals court with exclusive jurisdiction for patent cases. This court is referred to as the Court of Appeals for the Federal Circuit (CAFC) [11]. Since the CAFC's inception, its decisions have largely been viewed as expanding patent-eligible subject matter and strengthening the rights of patent holders relative to potential infringers. The PTO has followed suit, allowing innumerable biotechnology patents on a range of inventions from transgenic mice and leukemia-derived cell lines to recombinant drugs and vaccines.

In this legal and regulatory climate it was a small step for the PTO to combine the Supreme Court's decision in Chakrabarty with chemical law precedents upholding the validity of patents on purified, natural compounds such as aspirin [12], epinephrine [13], vitamin B 12 [14] and prostaglandins [15], so as to allow patents on another natural chemical, DNA. In the well-known US Federal Circuit case of Amgen v. Chugai Pharmaceutical Co. [16], the CAFC proclaimed, "A gene is a chemical compound, albeit a complex one". Since the Supreme Court's decision in Chakrabarty, the PTO has issued thousands of patents on DNA sequences, variants from normal or 'wild-type' sequences and associated genotype-phenotype correlations [5].

'When DNA is used as a chemical compound to produce recombinant drugs and vaccines, treating it as a complex chemical makes sense.'

Gene patents versus

personalized medicine

Section 101 of the Patent Act describes the subject matter that is eligible for patenting in the USA, stating, "W hoever invents or discovers any new and useful process, machine, manufacture or composition of matter, or any new and useful improvement thereof, may obtain a patent therefore, subject to the conditions and requirements of this title". Although the Supreme Court's decision in Chakrabarty mandated a broad interpretation of patent eligibility under section 101, the Court also emphasized that a patent's subject must be man made. In addition, patents may not be obtained on "laws of nature, natural phenomena and abstract ideas" [17].

These latter restrictions are particularly relevant to gene correlation patents in their application to molecular genetic testing. When D N A is used as a chemical compound to produce recombinant drugs and vaccines, treating it as a complex chemical makes sense. Recombinant drug production, for example, involves creation of a nucleic acid that did not previously exist in nature (CDNA), 
which is then used to produce another medically valuable chemical. Enormous investments are required to develop, test and obtain regulatory approval for pharmaceutical products. Patents on the human genes used to manufacture new drugs are central to the process of obtaining the risk capital needed to introduce these important therapeutic agents into medical practice.

'The intellectual property stemming from the development of novel tec hniques that can be automated to enable the accurate processing of large numbers of samples, rather than gene-related patents, has provided the stimulus for disc overy and investment in the field.'

By contrast, molecular genetic testing simply involves comparing a patient's DNA sequence with a reference sequence. D N A's sole utility in this context is as a store of biological information. Testing is not performed for the purpose of generating new molecules or products. M oreover, technical advancements have made the process of setting up molecular genetic tests scientifically straightforward, inexpensive and routine using justifiably patented in vitro DNAamplification techniques, such as PCR, and legitimately patented instruments such as thermal cyclers, real-time PCR systems and automated sequencers. The $\mathrm{H}$ uman $\mathrm{G}$ enome Project has made reference sequences freely available. The intellectual property stemming from the development of novel techniques that can be automated to enable the accurate processing of large numbers of samples, rather than generelated patents, has provided the stimulus for discovery and investment in the field.

As a result of the enormous technological advances that have taken place, many laboratories are capable of rapidly and inexpensively developing and/or validating both internally developed and commercially available molecular diagnostic tests of extraordinarily high sensitivity and specificity. However, allowing private ownership of the fundamental relationships between genetic variants and drug response threatens to dramatically limit the number of test providers, thereby reducing innovation and raising test costs at a time when high costs serve as a major barrier to the widespread introduction of pharmacogenetic testing.

As pharmacogenetic testing is performed for therapeutic assessment, rather than medical diagnosis, one can argue that the economics of the area differ from those of conventional genetic testing. The prospect of drug-related correlation patents, it can be asserted, will encourage pharmaceutical companies to invest heavily in discovery of these types of genotype-phenotype correlations. Since the acquisition of comprehensive data on the utility and application of clinically relevant genotype-phenotype relationships presents a major hurdle to the widespread use of pharmacogenetics in medical practice, any such encouragement would beneficially advance the discipline.

Although it is possible that there is some truth in the preceding analysis, selling drugs is typically far more profitable than performing diagnostic testing, a business in which pharmaceutical companies have not yet engaged. Instead, much of the economic worth of drug manufacturers will continue to emanate from patents on the therapeutic agents they invent. The value to them of patents on medicinally related genotype-phenotype correlations is a function of the extent to which these patents can be leveraged to strengthen existing patent protection for drugs and biologics and the degree to which exclusive control over drug-related genotype-phenotype correlations can be used to enhance the sales of their products.

'The expense of pharmacogenetic testing rela tive to the utility of the information provided is among the chief obstacles to its routine incorporation into medical practice. Therefore, any policy that promotes higher test costs is likely to impede the progress and advancement of personalized medic ine.'

Even if gene-related patents are helpful in fostering pharmacogenetic discoveries, will their positive effects sufficiently compensate for the resultant limitations on the number of test providers and the associated increases in costs? The answer is probably no. The expense of pharmacogenetic testing relative to the utility of the information provided is among the chief obstacles to its routine incorporation into medical practice. Therefore, any policy that promotes higher test costs is likely to impede the progress and advancement of personalized medicine. M ost pharmacogenetic relationships currently promoted for clinical use require analysis of only one or two genes. H owever, the heritable and somatically acquired genetic traits influencing most drugs' physiologic 
effects are likely to be polygenic. In the future, the inherent encumbrances that gene-related patents impose on all genetic testing will be magnified, as advancing knowledge necessitates the acquisition and integration of information regarding possible variants in multiple genes that act in concert.

\section{Gene-related patents \& the 'natural phenomenon' doctrine}

Fortunately, current US law does not appear to permit patents on human genes or patents on correlations between genetic variants and clinical phenotypes to be used to restrict diagnostic testing for inherited or acquired genetic traits [18]. Dating back to litigation over Samuel M orse's patents on the telegraph, US law has not allowed the patenting of natural phenomena [17,19]. In $O$ 'Reilly $v$. M orse, the validity of a patent on $M$ orse's invention was upheld. However, one claim in the patent went too far. In addition to patenting machinery that allowed him to transmit and print characters over wires, M orse also claimed the exclusive right to use electricity to do so.

The Supreme Court wisely recognized the dangers in allowing such patents on natural principles. In the deciding opinion, Justice Taney wrote, "If this claim can be maintained, it matters not by what process or machinery the result is accomplished. For aught that we now know some future inventor, in the onward march of science, may discover a mode of writing or printing at a distance ... without using any part of the process or combination in the plaintiff's [M orse's] specification. $\mathrm{H}$ is invention may be less complicated - less liable to get out of order - less expensive in construction and in its operation. But yet, if it is covered by this patent the inventor could not use it, nor the public have the benefit of it, without the permission of the patentee" [19]. The natural phenomenon doctrine has repeatedly been reaffirmed by the Supreme Court, most recently in Diamond v. Diehr [17], a dispute in which the Court upheld the validity of a patent on an automated process for molding uncured synthetic rubber into cured products.

'As we move toward persona lized medic ine, the detrimental effects of gene-related patents in the genetic -testing context a ppear to outweigh a ny possible benefits.'

This 'natural phenomenon' doctrine prohibits the patenting of laws of nature, for example gravity, relativity and biological relationships, such as the correlations between genetic changes and physical characteristics that are at the heart of all genetic testing. Although generelated patents that provide incentives for the creation of new biologics are useful and beneficial to society, their extension to include molecular genetic testing is not. As we move towards personalized medicine, the detrimental effects of gene-related patents in the genetic-testing context appear to outweigh any possible benefits. Therefore, it is in the public interest that our courts do not expand patent-eligible subject matter to include ownership of medically related genotype-phenotype correlations.

\section{Financial disclosure}

The author has no relevant financial, interests including employment, consultancies, honoraria, stock ownership or options, expert testimony, grants or patents received or pending, or royalties related to this manuscript.

\section{Bibliography}

1. Klein RD, Kant JA: O pportunity knocks: the pathologist as laboratory genetics consultant. Arch. Pathol. Lab. M ed. 130, 1603-1604 (2006).

2. Klein RD: The pain-protective haplotype: introducing the modern genetic test. Clin. Chem. 53, 1007-1009 (2007).

3. U S Patent and Trademark O ffice: 35 U SC 154(a)(2) Contents and term of patent; provisional rights. Appendix L Patent Laws.

4. U S Patent and Trademark O ffice: 35 U SC 101-103 Contents and term of patent; provisional rights. Appendix L Patent Laws.
5. Caulfield T, C ook-D eegan RM, Kieff FS, Walsh JP: Evidence and anecdotes: an analysis of human gene patenting controversies. N at. Biotechnol. 24, 1091-1094 (2006).

6. Leonard D GB: M edical practice and gene patents: a personal perspective. Acad. M ed. 77, 1388-1391 (2002).

7. Cho M K, Illangasekare $S$, W eaver M A, Leonard D GB, M erz JF: Effects of patents and licenses on the provision of clinical genetic testing services. J. M ol. Diagn. 5, 3-8 (2003).
8. US Patent and Trademark O ffice: 35 U SC 200-212 Contents and term of patent; provisional rights. Appendix $L$ Patent Laws.

9. Moses H, D orsey ER, M atheson DH M , Their SO : financial anatomy of biomedical research. JAM A 294, 1333-1342 (2005).

10. Diamond v. Chakrabarty, 447 U.S. 303 (1980).

11. Federal C ourts I mprovement Act of 1982, 96 Stat. 25, codified as 28 U.S.C. 1295 (2000).

12. Kuehmsted v. Farbenfabriken, 179 F. 701 (7th Cir. 1910), cert. denied, 220 US 622 (1911). 
13. Parke Davis \& Co. v. M ulford \& Co., $189 \mathrm{~F}$. 95 (S.D.N.Y. 1911), aff'd, 196 F. 496 (2d Cir. 1912).

14. M erck \& Co. v. O lin M athieson Chemical Corp., 253 F.2d 156 (4th Cir. 1958).

15. In re Bergstrom, 427 F.2d 1394 (C.C.P.A. 1970).

16. Amgen v. Chugai Pharmaceutical C $0 ., 927$ F.2d 1200 (1990), cert. denied, 502 U S 856 (1991).
17. Diamond v. Diehr, 450 U S 175 (1981).

18. Klein RD : M edical-process patents. N. Engl. J. M ed. 356, 753-754 (2007).

19. O'Reilly v. M orse, 56 (H ow.) US 62 (1853).

\section{Websites}

101. American Association for the Advancement of Science: Trends in Federal Research by Discipline, FY 1970-2005

www.aaas.org/spp/rd/discip05.pdf
102. US Patent and Trademark O ffice: US Colleges and U niversities - U tility Patent Grants 1969-2003

www.uspto.gov/web/offices/ac/ido/oeip/taf/ univ/asgn/table_1.htm 